\title{
The Effect of Immigration on Native Self-Employment
}

\author{
Robert W. Fairlie, University of California, Santa Cruz \\ Bruce D. Meyer, Northwestern University and National \\ Burean of Economic Research
}

\begin{abstract}
We examine the impact of immigration on self-employed natives. In a new general equilibrium model of self-employment and wage/salary work, a range of plausible parameter values implies small negative effects of immigration on native self-employment rates and earnings. Using 1980 and 1990 Census microdata, we then examine the relationship between changes in immigration and native self-employment rates and earnings across 132 of the largest U.S. metropolitan areas. We find evidence suggesting that self-employed immigrants displace self-employed natives but do not have a negative effect on native self-employment earnings. The effects are much larger than those predicted by the theoretical model.
\end{abstract}

\section{Introduction}

From 1981 to 1996 , over 12.5 million immigrants were legally admitted to the United States (Immigration and Naturalization Service [INS] 1997). Additionally, from 4.6 to 5.4 million undocumented immigrants are estimated to have resided in the United States in October 1996 (INS 1997).

We would like to thank Doug Miller and seminar participants at the University of California, Berkeley; Northwestern University; and the Santa Cruz Center for International Economics Conference on Labor and Capital in the Global Economy for their comments and suggestions. Partial support for Fairlie was provided by National Science Foundation Grant SBR-9809266. Steven Anderson, Alessandra Cassar, and Bill Koch provided research assistance.

[Journal of Labor Economics, 2003, vol. 21, no. 3]

(C) 2003 by The University of Chicago. All rights reserved. 0734-306X/2003/2103-0005\$10.00 
A rapidly growing literature examines the impact of these immigrants on the labor market outcomes of native-born Americans. ${ }^{1}$ Most previous studies focus on the effects of immigration on the wages and employment of less-skilled native-born workers. However, the impact of immigration on native self-employment-another segment of the labor force that contains a disproportionate number of immigrants-has not been examined. ${ }^{2}$ We address this gap in the literature by exploring whether self-employed immigrants displace self-employed natives and depress their earnings.

The impact of immigration on the self-employed might be greater than that on wage/salary workers for several reasons. Recent research that seeks to explain the small impact of immigration on native wage/salary workers has pointed to migration and capital flows as offsetting factors. ${ }^{3}$ Outmigration of natives and the inflow of capital may offset the impact of immigration on an area. The ability to export output from a geographic area may also limit the impact of an immigrant inflow. These amelioratory forces are likely to be less important for the self-employed, who tend to be less mobile, do not typically rely on long-distance financing, and tend to sell locally. ${ }^{4}$ Thus, we might expect a greater effect of immigration on the self-employed.

An analysis of the effects of immigration on the self-employment prospects of native-born Americans is important for several reasons. First, immigrants may limit the opportunities for disadvantaged native ethnic groups to use business ownership as a route of economic advancement. ${ }^{5}$ Overall, a high self-employment rate for an ethnic or racial group is strongly associated with a high average income for that group, ${ }^{6}$ and, despite likely underreporting, the self-employed earn more on average than wage and salary workers. Second, self-employment is also viewed as a potential route out of poverty, leading to its promotion by states and the federal government as a way to leave the welfare and unemployment

${ }^{1}$ See Borjas (1994) and Friedberg and Hunt (1995) for reviews of this literature.

2 The 1990 Census microdata indicate that self-employment rates for immigrants are $23 \%$ higher than those for natives in the United States. For further evidence of higher immigrant self-employment rates, see Borjas (1986), Yuengert (1995), and Fairlie and Meyer (1996).

${ }^{3}$ See, e.g., Borjas, Freeman, and Katz (1996, 1997).

${ }^{4}$ As noted below, we find lower 5-year migration rates for the self-employed than for wage/salary workers using Census microdata. Data from Characteristics of Business Owners (CBO) indicate that $87 \%$ of small businesses describe their marketplace as the "neighborhood" or the "city/county" (U.S. Bureau of the Census 1996).

${ }^{5}$ Glazer and Moynihan (1970, p. 36) argue that "business is in America the most effective form of social mobility for those who meet prejudice." In addition, Fairlie (forthcoming) finds that young less educated business owners experience faster earnings growth than their counterparts in the wage/salary sector.

${ }^{6}$ See sec. 6 of Fairlie and Meyer (1996). 
insurance rolls. ${ }^{7}$ Third, ethnic and racial business ownership patterns contribute to tensions between groups. ${ }^{8}$ Fourth, it has been argued that political influence comes with small business success. ${ }^{9}$ Finally, an examination of the impact of immigration on native self-employment is of interest for the same reasons that we are interested in the impact of immigration on the wages and employment of native-born wage and salary workers. The extent to which immigrants displace native workers from their jobs and bid down their wages determines one of the main costs of immigration and affects political support for U.S. immigration policies.

In previous work (Fairlie and Meyer 1998), we estimated the effect of immigration on the self-employment prospects of native-born blacks. We generally found that immigration has no effect or only a small negative but statistically insignificant effect on black self-employment. This finding, however, does not rule out the possibility that there is a large negative effect on the self-employment prospects of native nonblacks. Self-employed native-born Europeans, Hispanics (of white race), or Asians may be more concentrated in the neighborhoods and industries in which selfemployed immigrants tend to locate. ${ }^{10}$ Furthermore, self-employed nonblacks represent $96 \%$ of all self-employed natives, potentially placing a larger number of them at risk of displacement than self-employed native blacks.

In this article, we extend the analysis in Fairlie and Meyer (1998) to include an examination of the effects of immigration on the self-employment prospects of native-born nonblacks. ${ }^{11}$ Larger sample sizes for non-

${ }^{7}$ For descriptions of these programs, see Guy, Doolittle, and Fink (1991) and Raheim (1997) on the Aid to Families with Dependent Children (AFDC) program and U.S. Department of Labor (1992) and Benus et al. (1992) on the Unemployment Insurance (UI) program.

${ }^{8}$ The recent racial conflicts between Koreans and African Americans in many large cities are in large part due to the presence of Korean-owned businesses in black communities (see Yoon 1991; and Min 1996).

${ }^{9}$ See Brown, Hamilton, and Medoff (1990).

${ }^{10}$ Prior to the large inflows of immigrants in the past 3 decades, Ivan Light (1972, p. 3) noted that "in every large black neighborhood in the United States, white proprietors virtually monopolize local retail trade," suggesting that, even in black neighborhoods, self-employed whites may have been at a higher risk of being displaced by self-employed immigrants than self-employed blacks. A more specific example is provided by Yoon (1997), who notes that Korean-owned businesses moved into parts of Chicago's West and South sides that were previously dominated by Jewish- and Italian-owned businesses.

${ }^{11}$ Two previous studies use aggregate data from the 1980 Census to examine the effects on whites (Light and Sanchez 1987; Light and Rosenstein 1995). These studies find that the immigrant self-employment rate and the immigrant share of the total self-employed have essentially no effect on the self-employment rates or self-employment earnings of native whites. We contribute to these results by using data from both 1980 and 1990 and by including metropolitan area fixed 
blacks than for blacks allow us to estimate the effects of immigration on the earnings of self-employed natives and to include more metropolitan areas of the United States in our sample. We also present a new general equilibrium model of self-employment and wage/salary work. This theoretical model predicts how an influx of immigrants would affect the native self-employment rate and earnings in the self-employment sector. For a range of plausible parameter values, the model predicts small effects of immigration on native self-employment rates and earnings.

Using 1980 and 1990 U.S. Census microdata, we examine the relationship between changes in immigration and native self-employment rates and earnings across 132 of the largest metropolitan areas in the United States. ${ }^{12}$ We find evidence supporting the hypothesis that self-employed immigrants displace self-employed natives. Immigrants, however, do not have a negative effect on native self-employment earnings. Our findings are similar if we weight immigration rates by the propensity of immigrant groups to be self-employed or if we try alternative estimation techniques and specifications.

\section{A Formal Model of the Effects of Immigration}

A formal model is useful to assess the likely impact of immigration flows on the self-employment prospects of natives. We are interested in the effect of immigration on both the self-employment earnings and the self-employment rate of natives. As in past work, such as that of Altonji and Card (1991) and Borjas (1994), we view each labor market as a closed economy. Like this other research, we allow immigration to have an effect on product demand and, consequently, labor demand, as well as on labor supply. In short, immigration increases the supply of those entering self-employment, but it also increases the demand for the output of the self-employed. The relative importance of these shifts in supply and demand will then determine the change in the return to self-employment and the self-employment rate.

Our model differs from the models mentioned above in that it allows occupational choice (self employment vs. wage/salary work) but assumes that only one type of skill is used in each sector. The earlier models mentioned above assume that workers differ in their skills and that firms can substitute one skill for another to some extent. These fixed worker skills determine where each person works. Differences between immigrants and natives come about because the two groups are allowed to differ in their skill composition. In contrast, in our model, workers choose

effects. We also include individual-level controls in our regressions, employ instrumental variables techniques, and try specifications in which our measure of immigration is weighted by the propensity of different immigrant groups to choose self-employment.

${ }^{12}$ For brevity, we refer to nonblack natives as natives in the remainder of the article. 
to supply their labor to a sector based on its wage and possibly other characteristics. Immigrants and natives are allowed to differ in these labor supply functions as well as their product demand functions. These differences in supply and demand functions can be due to differences in skill composition or to different preferences for job autonomy or other nonwage characteristics such as hours of work.

Let there be two producing sectors, the self-employment sector and the wage/salary sector, each with its own good. We divide the population into immigrants and natives, letting the two groups have possibly different demand functions for the two goods and possibly different labor supply functions to the two sectors. In the model, wages, prices, employment, and output in the two sectors are endogenously determined.

To flesh out the model, assume that the self-employment and wage/ salary sectors use labor to produce $Q_{s}$ and $Q_{w}$ units of aggregate selfemployment and wage/salary output, respectively. We ignore capital as an input for simplicity. ${ }^{13}$ Each sector has an aggregate constant returns to scale technology, so that the unit cost functions in the two sectors can be written as $\alpha_{s} W_{s}$ and $\alpha_{w} W_{w}$, where $W_{s}$ and $W_{w}$ are the wage rates in the two sectors. Assuming that each sector is perfectly competitive implies that prices in the two sectors are $P_{s}=\alpha_{s} W_{s}$ and $P_{w}=\alpha_{w} W_{w}$.

On the individual demand side, we take there to be $N^{i}$ immigrants and $N^{n}$ natives, each with individual demand functions $D_{j}^{i}\left(W_{s}, W_{w}, P_{s}, P_{w}\right)$ and $D_{j}^{n}\left(W_{s}, W_{w}, P_{s}, P_{w}\right)$, respectively, where $j \in\{s, w\}$ denotes the self-employment or wage/salary sector. On the labor supply side, we write the per person immigrant and native labor supply functions to the two sectors as $L_{j}^{i}\left(W_{s}, W_{w}, P_{s}, P_{w}\right)$ and $L_{j}^{n}\left(W_{s}, W_{w}, P_{s}, P_{w}\right)$, respectively. Normalizing $P_{w}=1$ and using the constant returns to scale assumption implies that $P_{w}$ and $W_{w}$ are fixed. We write the product demand functions with $P_{s}$ as their only argument, and we write the labor supply functions with $W_{s}$ as their only argument. ${ }^{14}$

Product market equilibrium requires that product demand equals output, or

$$
\begin{gathered}
Q_{s}=N^{i} D_{s}^{i}\left(P_{s}\right)+N^{n} D_{s}^{n}\left(P_{s}\right), \\
Q_{w}=N^{i} D_{w}^{i}\left(P_{s}\right)+N^{n} D_{w}^{n}\left(P_{s}\right) .
\end{gathered}
$$

${ }^{13}$ We should note that other work has found capital constraints to be an important feature of self-employment (for examples, see Holtz-Eakin et al. 1994; and Blanchflower and Oswald 1998).

${ }^{14}$ We use this notation even though $P_{s}$ and $W_{s}$ are proportional to each other given the constant returns to scale assumption. As we discuss later, the price is the main determinant of product demand, and the wage is the main determinant of labor supply. 
Labor market equilibrium requires that labor supply equal labor demand in each sector, or

$$
\begin{gathered}
Q_{s} \boldsymbol{\alpha}_{s}=N^{i} L_{s}^{i}\left(W_{s}\right)+N^{n} L_{s}^{n}\left(W_{s}\right), \\
Q_{w} \boldsymbol{\alpha}_{w}=N^{i} L_{w}^{i}\left(W_{s}\right)+N^{n} L_{w}^{n}\left(W_{s}\right) .
\end{gathered}
$$

We then examine the effect of an increase in the number of immigrants on the wage of the self-employed. Using (1) and (3), we obtain

$$
\alpha_{s} N^{i} D_{s}^{i}\left(P_{s}\right)+\alpha_{s} N^{n} D_{s}^{n}\left(P_{s}\right)=N^{i} L_{s}^{i}\left(W_{s}\right)+N^{n} L_{s}^{n}\left(W_{s}\right) .
$$

Differentiating this equation, we have

$$
\begin{gathered}
\alpha_{s} d N^{i} D_{s}^{i}+\alpha_{s} N^{i} \frac{d D_{s}^{i}}{d P_{s}} \frac{d P_{s}}{d W_{s}} d W_{s}+\alpha_{s} N^{n} \frac{d D_{s}^{n}}{d P_{s}} \frac{d P_{s}}{d W_{s}} d W_{s} \\
=d N^{i} L_{5}^{i}+N^{i} \frac{d L_{s}^{i}}{d W_{s}} d W_{s}+N^{n} \frac{d L_{s}^{n}}{d W_{s}} d W_{s} .
\end{gathered}
$$

A change to elasticities and some algebra gives us

$$
\frac{d W_{s} / W_{s}}{d N^{i} / N}=\frac{P_{s} D_{s}^{i}-W_{s} L_{s}^{i}}{\beta W_{s} L_{s}^{i} \varepsilon_{s}^{i}+(1-\beta) W_{s} L_{s}^{n} \varepsilon_{s}^{n}-\beta P_{s} D_{s}^{i} \eta_{s}^{i}-(1-\beta) P_{s} D_{s}^{n} \eta_{s}^{n}} \equiv \gamma,
$$

where

$$
N=N^{i}+N^{n}, \beta=\frac{N^{i}}{N},(1-\beta)=\frac{N^{n}}{N},
$$

$\varepsilon_{s}^{i} \equiv\left(d L_{s}^{i} / d W_{s}\right)\left(W_{s} / L_{s}^{i}\right)$ is the immigrant elasticity of labor supply to the self-employment sector, $\varepsilon_{s}^{n} \equiv\left(d L_{s}^{n} / d W_{s}\right)\left(W_{s} / L_{s}^{n}\right)$ is the native elasticity of labor supply to the self-employment sector, $\eta_{s}^{i} \equiv\left(d D_{s}^{i} / d P_{s}\right)\left(P_{s} / D_{s}^{i}\right)$ is the immigrant elasticity of demand for self-employment output, and $\eta_{s}^{n} \equiv$ $\left(d D_{s}^{i} / d P_{s}\right)\left(P_{s} / D_{s}^{n}\right)$ is the native elasticity of demand for self-employment output. $^{15}$

Equation (7) has a nice interpretation. The numerator is the value of self-

${ }^{15}$ We should emphasize that, while labor supply depends on $P_{s}$ as well as $W_{s}$, the role of $P_{s}$ will be relatively small. Analogously, while product demand depends on $W_{s}$ as well as $P_{s}$, the role of $W_{s}$ will be relatively small. To see this point, realize that labor supply should depend on the relative wage in self-employment (which only depends on $\left.W_{s}\right)$ and real income. Real income is $\left(W_{s} L_{s}+W_{w} L_{w}\right) /\left(P_{s} D_{s}+\right.$ $\left.P_{w} D_{w}\right)$ (dropping the superscripts for now). A given percentage change in $W_{s}$ will have a much bigger effect through the real wage than the same percentage change in $P_{s}$ will through real income since $L_{s}$ and $D_{s}$ are so much smaller than $L_{w}$ and $D_{w}$, and because the changes in $W_{s}$ and $P_{s}$ will mostly cancel each other in the real wage. Similarly, the demand for self-employment output should depend on its relative price (which only depends on $P_{s}$ ) and real income, and the influence of $W_{s}$ through real income will be small. 
employment output consumed by each immigrant minus the value of selfemployment output produced by each immigrant. The effect of immigration on the wage in self-employment depends on whether immigrants produce more self-employment output than they consume. When immigrant consumption is less than output, the wage in self-employment falls when immigration rises. The wage in self-employment rises with immigration when the opposite is true. In other words, immigration shifts out the supply curve of self-employment labor, but it also shifts out the demand curve for selfemployment labor by shifting out the demand for self-employment output. The relative size of these effects determines the sign and magnitude of the effect of immigration on the self-employment wage. The magnitude of any change in the wage is also determined by the denominator, which is a total labor supply share and output share weighted sum of labor supply and output demand elasticities. All of the terms in the denominator are positive.

We can now use the above equations to calculate the type of derivatives empirically estimated in Section IV. These derivatives give the implied change in the number of natives who are self-employed when the number of self-employed immigrants rises by one:

$$
\frac{d L_{s}^{n}}{d N^{i}} \frac{N^{n}}{L_{s}^{i}}=\varepsilon_{s}^{n} \gamma(1-\beta) \frac{L_{s}^{n}}{L_{s}^{i}} .
$$

To provide an idea of the magnitude of the expressions in equations (7) and (8), we calculate them under various assumptions. For simplicity, we assume that immigrant and native supply and demand elasticities are the same, that is, that $\varepsilon_{s}^{i}=\varepsilon_{s}^{n}=\varepsilon$ and $\eta_{s}^{i}=\eta_{s}^{n}=\eta$. Different elasticities for immigrants and natives would not appreciably alter the results, as one can see by examining the denominator of (7). We also assume that $P_{s} D_{s}^{i}=W_{s} L_{s}^{n} \equiv \delta$ and that $W_{s} L_{s}^{i} \equiv \rho \delta, \rho>1$. Note that if $P_{s} D_{s}^{i}=W_{s} L_{s}^{i}$, the expressions in (7) and (8) are zero, so that immigration has no effect on native self-employment. Equating product supply and demand in the selfemployment sector then implies that

$$
P_{s} D_{s}^{n}=\delta\left[1+\frac{\beta}{(1-\beta)}(\rho-1)\right] .
$$

Under these assumptions, (7) becomes

$$
\begin{aligned}
\frac{\left(d W_{s} / W_{s}\right)}{\left(d N^{i} / N\right)} & =\frac{1-\rho}{\beta \varepsilon \rho+(1-\beta) \varepsilon-\beta \eta-(1-\beta) \eta\left[1+\frac{\beta}{1-\beta}(\rho-1)\right]} \\
& \approx \frac{-(\rho-1)}{\varepsilon+|\eta|},
\end{aligned}
$$


Table 1

Simulated Effects of Immigration on Native Wage and Native Employment in the Self-Employment Sector

\begin{tabular}{|c|c|c|c|c|c|c|}
\hline \multirow[b]{2}{*}{ Simulation } & \multicolumn{4}{|c|}{ Simulation Parameters } & \multicolumn{2}{|c|}{ Implied Effects of Immigration } \\
\hline & $\epsilon$ & $\eta$ & $\beta$ & $\rho$ & $\left(d W_{s} / W_{s}\right) /\left(d N^{i} / N\right)$ & $\left(d L_{s}^{n} / d N^{i}\right)\left(N^{n} / L_{s}^{i}\right)$ \\
\hline 1 & .20 & -.20 & .12 & 1.20 & -.488 & -.072 \\
\hline 2 & .50 & -.50 & .12 & 1.20 & -.195 & -.072 \\
\hline 3 & 1.00 & -1.00 & .12 & 1.20 & -.098 & -.072 \\
\hline 4 & 2.00 & -2.00 & .12 & 1.20 & -.049 & -.072 \\
\hline 5 & .20 & -.20 & .12 & 1.30 & -.724 & -.098 \\
\hline 6 & .50 & -.50 & .12 & 1.30 & -.290 & -.098 \\
\hline 7 & 1.00 & -1.00 & .12 & 1.30 & -.145 & -.098 \\
\hline 8 & 2.00 & -2.00 & .12 & 1.30 & -.072 & -.098 \\
\hline
\end{tabular}

and (8) becomes

$$
\frac{d L_{s}^{n}}{d N^{i}} \frac{N^{n}}{L_{s}^{i}}=\frac{\left(d W_{s} / W_{s}\right)}{\left(d N^{i} / N\right)} \frac{\varepsilon(1-\beta)}{\rho} \approx \frac{-\varepsilon(\rho-1)}{\rho(\varepsilon+|\eta|)} .
$$

In table 1, we report our simulated effects of immigration on the native wage and employment in the self-employment sector using equations (9) and (10). We take $\beta$, the immigrant share of employment, to be 0.12 , the 1990 share for the metropolitan areas we examine (see Sec. III). We take $\rho$, the ratio of immigrant to native per capita supply to the self-employment sector, to be either 1.2 or 1.3 , numbers that bracket the 1990 ratio (see n. 2). We consider a wide range of plausible values for $\epsilon$ and $\eta(0.2$ to 2.0 in absolute value). The larger values are probably more plausible, because these sector-specific elasticities should be larger than overall elasticities since they reflect substitution between the two sectors. The implied effect of immigration on native self-employment earnings rises as $\epsilon$ and $\eta$ fall and as $\rho$ rises. The effect of immigration on earnings is small except when the assumed supply and demand elasticities are very small. In all cases, the effect on the native self-employment rate is small. For example, when we set $\rho=1.3$ and take the supply and demand elasticities to be equal to 1 , the elasticity of self-employment earnings with respect to immigration is -0.145 , and the number of natives displaced by each selfemployed immigrant is under 0.10 . Overall, the model assumptions imply very small effects of immigration on both native self-employment earnings and the native self-employment rate.

While this base model implies little effect of immigration on the selfemployment of natives, it is worth asking what alternative assumptions might lead to substantial effects of immigration. One of the maintained assumptions is that there is only one type of self-employment output from the perspective of consumers. This assumption requires that immigrants do not differentiate in their demand between the self-employ- 
ment output of immigrants and natives. If immigrants buy only from other immigrants, immigrants would have a greater effect on wages and the employment of natives. This assumption also requires that immigrants do not produce a different output, so that they are not clustered in certain segments of the market. If such clustering occurs, it might lead to a greater fall in employment than predicted earlier. Another possibility is that immigrants have very low levels of demand for self-employment output, possibly caused by low levels of income among immigrants and resulting low demands for "luxury" services, such as cleaning and gardening, that are often provided by the self-employed. Finally, if immigrants are better at producing certain types of self-employment output than are natives, they would more likely crowd out natives in those sectors. ${ }^{16}$ If these immigrant industries are low-earnings self-employment sectors, this crowding out might lead the average measured self-employment earnings of natives to rise, as those with low earnings are driven out. An example of this last possibility is that ethnic restaurants might crowd out less expensive native-owned restaurants but not crowd out more expensive native-owned restaurants. This event would result in a negative effect on the native self-employment rate but a positive effect on native self-employment earnings. However, several of these stories would suggest that we should see higher immigrant self-employment rates than we do see. It is also not clear that the clustering of immigrants in a few sectors would lead to a larger aggregate effect. A large effect in a few small sectors might not lead to a large aggregate effect given the size of the sectors. Therefore, it is unclear how much weight to put on these possibilities, but these examples illustrate the types of situations that would be needed to produce substantial effects of immigration on native self-employment.

\section{Data}

The data used in this study are from the Public Use Microdata 5-Percent Samples of the 1980 and 1990 U.S. Censuses of Population. These datasets are the only sources of national microdata that are large enough to allow comparisons of native self-employment rates across a large number of metropolitan areas. In addition, they are preferable to published aggregate data because they provide more flexibility in creating sample restrictions and definitions of key variables and because they allow us to directly control for individual-level characteristics in our regressions. Finally, the detailed geographical information in the Census makes it possible to create consistent metropolitan area definitions over time.

\footnotetext{
${ }^{16}$ Kinzer and Sagarin (1950), Glazer and Moynihan (1970), and Light (1972) make the argument that immigrant business owners have an advantage in providing special services and goods to co-ethnics.
} 


\section{A. Definitions and Sample Restrictions}

Self-employed workers are defined as those individuals who identify themselves as mainly self-employed in their own not incorporated or incorporated business on the class of worker question. ${ }^{17}$ In 1990, the relevant choices on the Census questionnaire were (6) "SELF-EMPLOYED in own NOT INCORPORATED business, professional practice, or farm" and (7) "SELF-EMPLOYED in own INCORPORATED business, professional practice, or farm" (U.S. Bureau of the Census, 1993, E-15). ${ }^{18}$ In $1990,34.0 \%$ of all self-employed men and $24.2 \%$ of all selfemployed women reported having their own incorporated business.

In our study, we include only individuals of ages 16-64 years, and we impose additional sample restrictions depending on the measure of selfemployment that we are using. Our first measure, the self-employment rate, is defined as the fraction of workers that is self-employed. We include only individuals who worked at least 20 weeks in the past year and usually worked at least 15 hours per week during that year. As in most previous studies of self-employment, we include only workers in nonagricultural industries. The second measure, the self-employment ratio, is defined as the fraction of the total population that is self-employed. The sample used to calculate this self-employment ratio is not restricted to include only workers. Instead, we only exclude individuals who are currently enrolled in school or who are institutionalized. Therefore, agricultural workers, the unemployed, and workers with few total annual hours are included in the calculation of the self-employment ratio but not in the self-employment rate. The self-employment rate measure is more in line with our formal model, which does not incorporate unemployment and hours responses to immigration. The self-employment ratio does reflect possible changes in unemployment and hours and might be preferred on those grounds. We provide estimates using both measures of self-employment in most of the analyses discussed below.

\section{B. Metropolitan Area Sample, Native Self-Employment, and Immigration}

To assess the effects of immigration on native self-employment, we examine differences in immigration and self-employment across geographic areas. These geographic areas should approximate labor markets for the self-employed. We take the standard approach in the literature, which uses metropolitan areas (MAs) as the geographic areas. The specific

${ }^{17}$ Unpaid family workers are not counted as self-employed.

${ }^{18}$ The "class of worker" question refers to the individual's "chief job activity or business last week." Individuals who hold more than one job are asked to refer to the one at which they worked the most hours. The "class of worker" question on the 1980 Census is nearly identical. 
Table 2

Native Self-Employment Measures and Immigrant Share for the 132 Metropolitan Areas Sample, 1980 and 1990 Censuses

\begin{tabular}{llcc}
\hline & 1980 & 1990 & Change \\
\hline Native men: & & & \\
Self-employment rate (\%) & 10.0 & 10.5 & .5 \\
Self-employment ratio (\%) & 10.9 & 11.5 & .6 \\
Mean log SE earnings (rate) & 10.22 & 10.17 & -.04 \\
Mean log SE earnings (ratio) & 9.70 & 9.70 & .00 \\
Native women: & 3.7 & 5.6 & 2.0 \\
Self-employment rate (\%) & 3.3 & 5.7 & .18 \\
Self-employment ratio (\%) & 8.99 & 9.17 & .40 \\
Mean log SE earnings (rate) & 7.66 & 8.05 & 3.6 \\
Mean log SE earnings (ratio) & 8.4 & 12.1 & 132 met- \\
Immigrant share of population (\%) & & & \\
Note. - Data are from a sample of native-born nonblacks aged 16-64 years living in 130 & \\
ropolitan areas. The self-employment rate is the fraction of the employed that is self-employed. The \\
self-employment ratio is the fraction of the noninstitutional, not-in-school population that is self- \\
employed. Census sample weights are used in 1990.
\end{tabular}

MA definitions we use follow Bound and Holzer (1996) and Jaeger (1996)..$^{19}$ These definitions combine detailed geographical areas identified in the Censuses to provide consistent or nearly consistent definitions of 132 metropolitan areas in 1980 and 1990. These metropolitan areas create a sample that represents $68.5 \%$ of the U.S. native nonblack population (ages 16-64) in 1980 and $69.5 \%$ in 1990 . The sample also captures $90.0 \%$ and $91.7 \%$ of the immigrant population (ages 16-64) in 1980 and 1990 , respectively.

To see if immigrant and native self-employed are likely to be competing in the same markets, we examined the industry distributions of both groups in 1990 (a summary table with separate numbers for men and women is provided in the appendix as table A1). For the most part, immigrants and natives have similar industry distributions. Some exceptions to this generalization are that native men are more likely than immigrant men to be in construction and professional services and less likely to be in retail trade. Native women are more likely than immigrant women to be located in professional services and less likely to be in retail trade. In more detailed industry analyses, which we do not report, we find that immigrant men are relatively concentrated in restaurants, grocery stores, and taxicabs. Immigrant women are relatively concentrated in restaurants, cleaning services, grocery stores, and laundries. However, besides these exceptions, the differences between immigrants and natives are not large, so that self-employed immigrant men and women have fairly similar industry distributions.

In table 2, we report native self-employment rates and ratios and average

${ }^{19}$ See Loeb, Turner, and Jaeger (1996) for a description of the geographic matching process. 
native self-employment earnings by gender and year for our sample of $132 \mathrm{MAs.}^{20}$ The self-employment rate and self-employment ratio for natives are defined as above. From 1980 to 1990, the self-employment rate and ratio increased substantially for native women but only slightly for native men. The increase for native women agrees with other evidence on increases in female self-employment (see Devine 1994; and U.S. Small Business Administration 1998).

In table 2, we also report mean log self-employment earnings (in 1990 US\$) for self-employed natives meeting the sample restrictions for the self-employment rate and ratio. ${ }^{21}$ The results indicate that average earnings increased rapidly from 1980 to 1990 for self-employed native women but remained essentially the same for self-employed native men. Finally, we report the immigrant share, which is defined as the fraction of the total population (ages 16-64) that is immigrant. The immigrant share increased from $8.4 \%$ to $12.1 \%$ from 1980 to 1990 for our sample of MAs.

The combination of the upward trend in the immigrant share and the upward trends in native self-employment rates and self-employment earnings (at least for women) does not provide support for the crowding out hypothesis. These trends, however, do not rule out the possibility that native self-employment and self-employment earnings declined substantially in MAs that received large inflows of immigrants, while increasing in other MAs. We investigate this possibility further in the next section using our sample of 132 MAs.

\section{Results}

We are interested in obtaining estimates of the size of the effects of immigration on native self-employment rates and earnings and in determining whether these effects are statistically different from zero. We also would like to control for individual- and MA-level characteristics that affect self-employment rates and earnings. We accomplish these goals by estimating equations for the probability of self-employment and selfemployment earnings using our sample of natives residing in one of the 132 MAs.

\section{A. Estimating the Effects of Immigration on Native Self-Employment}

We first examine the effect of immigration on the native self-employment rate. We estimate this effect using probit regressions for the prob-

\footnotetext{
${ }^{20}$ The reported values of these measures are similar to those for the entire United States.

${ }^{21}$ There are many conceptual difficulties in measuring the return to self-employment using the type of information available in household surveys such as the Census. Reported earnings likely include returns on the self-employed individual's capital.
} 
ability of self-employment among native-born Americans. We expect there to be part of the error term in the underlying choice equation that is common across all observations from an MA, in part because there are unobserved characteristics of MAs for which we cannot control. Due to the presence of this MA-level error component, we estimate a random effects probit regression to obtain efficient coefficient estimates and correct standard errors. Following Borjas and Sueyoshi (1994), we estimate the random effects probit in two stages. ${ }^{22}$ The first stage consists of a probit regression using individual-level data:

$$
\operatorname{Pr}\left(Y_{i m}=1\right)=\Phi\left(X_{i m}^{\prime} \beta+\alpha_{m}\right),
$$

where $Y_{i m}=1$ if the individual is self-employed, $\Phi$ is the standard normal cumulative distribution function, $X_{i m}$ is a vector of individual-level characteristics, and $\alpha_{m}$ is a fixed effect for MA $m, m=1, \ldots, 132$. The second stage consists of a linear regression of the estimates of $\alpha_{m}$ on the MAlevel variables:

$$
\hat{\alpha}_{m}=Z_{m}^{\prime} \gamma+u_{m}
$$

where $Z_{m}$ includes the immigrant share and other MA-level characteristics. The fixed effects in this equation are transformations of MA self-employment rates after controlling for differences in individual-level characteristics across MAs. Therefore, (12) is a regression of the adjusted selfemployment tendency in an MA on MA-level variables. The second-stage coefficient estimates from (12) are in the same metric as the probit coefficients in (11), and their standard errors account for the group-level component in the error term.

As suggested in Borjas and Sueyoshi (1994), we estimate the secondstage regression using generalized least squares (GLS). Specifically, we use the weighting matrix $\Omega=\sigma_{u}^{2} I_{M}+V_{\alpha \alpha}$, where $V_{\alpha \alpha}$ is the $M \times M$ block of the covariance matrix from (11) that is associated with the fixed effects $\left(\alpha_{m}\right) .{ }^{23}$ The use of $\Omega$ places different weights on each MA, which are related to the inverse of the precision of its fixed effect in the first-stage probit regression.

We estimate two-stage probit regressions for men and women using two different measures of self-employment and immigration. The sample sizes used in the first-stage probit regressions range from 1.1 to 1.8 million observations. For computational reasons, we estimate these probit regressions using a choice-based sampling maximum likelihood estimator (CBSMLE). ${ }^{24}$ The sample used for this estimator includes all of the observations in which the dependent variable equals one and an equal-sized

\footnotetext{
${ }^{22}$ See Fairlie and Meyer (1998) for a more thorough discussion.

${ }^{23}$ We estimate $\sigma_{u}^{2}$ following Borjas (1987).

${ }^{24}$ See Amemiya (1985) for more details.
} 
Table 3

Two-Stage Probit Estimates for Probability of Self-Employment, 1980 and 1990, Second-Stage Regressions

\begin{tabular}{|c|c|c|c|c|}
\hline & \multicolumn{2}{|c|}{$\begin{array}{c}\text { Self-Employment } \\
\text { Rate }\end{array}$} & \multicolumn{2}{|c|}{$\begin{array}{l}\text { Self-Employment } \\
\text { Ratio }\end{array}$} \\
\hline & $\begin{array}{c}1980 \\
\text { GLS } \\
(1)\end{array}$ & $\begin{array}{c}1990 \\
\text { GLS } \\
(2)\end{array}$ & $\begin{array}{c}1980 \\
\text { GLS } \\
(3)\end{array}$ & $\begin{array}{c}1990 \\
\text { GLS } \\
(4)\end{array}$ \\
\hline \multicolumn{5}{|l|}{ Native men: } \\
\hline Immigrant share & $\begin{array}{l}1.0369 \\
(.1817)\end{array}$ & $\begin{array}{c}.6421 \\
(.1309)\end{array}$ & $\begin{array}{c}.6142 \\
(.1817)\end{array}$ & $\begin{array}{c}.5439 \\
(.1195)\end{array}$ \\
\hline Scaled derivative & 1.0036 & .4989 & .5712 & .4048 \\
\hline Weighted immigrant share & $\begin{array}{l}1.4166 \\
(.2397)\end{array}$ & $\begin{array}{l}.8538 \\
(.1711)\end{array}$ & $\begin{array}{l}.8055 \\
(.2460)\end{array}$ & $\begin{array}{c}.7036 \\
(.1582)\end{array}$ \\
\hline Scaled derivative & 1.3711 & .6635 & .7491 & .5236 \\
\hline \multicolumn{5}{|l|}{ Native women: } \\
\hline Immigrant share & $\begin{array}{c}.6744 \\
(.1696)\end{array}$ & $\begin{array}{l}.4716 \\
(.1105)\end{array}$ & $\begin{array}{c}.4772 \\
(.1579)\end{array}$ & $\begin{array}{c}.4207 \\
(.1049)\end{array}$ \\
\hline Scaled derivative & .2095 & .1832 & .1842 & .1881 \\
\hline Weighted immigrant share & $\begin{array}{r}.7439 \\
(.2198)\end{array}$ & $\begin{array}{c}.5729 \\
(.1437)\end{array}$ & $\begin{array}{c}.5138 \\
(.2094)\end{array}$ & $\begin{array}{c}.4883 \\
(.1385)\end{array}$ \\
\hline Scaled derivative & .2311 & .2226 & .1983 & .2183 \\
\hline
\end{tabular}

Note.-Data are from a sample of native-born nonblacks aged 16-64 years living in 132 metropolitan areas. Standard errors are in parentheses. The scaled derivative approximates the change in the number of self-employed natives when the number of self-employed immigrants increases by one. The weighted immigrant share weights immigrant groups by their self-employment rate (or ratio). All specifications include $\log$ average income of natives, native unemployment rate, and log native population.

random sample of observations in which the dependent variable equals zero. The likelihood function is then weighted appropriately. ${ }^{25}$ The resulting sample sizes range from 80,710 to 409,533 observations. In these first-stage probit regressions, we include individual-level controls for age, education level, marital status, number of children, disability status, and veteran status. ${ }^{26}$ We do not report these results. Instead, we focus on the results of the second-stage regressions.

In table 3, we report estimates of the effects of the immigrant share and the weighted immigrant share (described below) from the secondstage regressions using our two measures of self-employment. Specifications 1 and 3 use the 1980 cross-section, and specifications 2 and 4 use the 1990 cross-section. All second-stage regressions include the reported immigration measure and additional MA-level controls. ${ }^{27}$ The inclusion

${ }^{25}$ Observations in which $Y=0$ and $Y=1$ are given weights of $p / 0.5$ and $(1-$ $p) / 0.5$, respectively, where $p$ is the proportion of ones in the original sample.

${ }^{26}$ The coefficient estimates on these variables are consistent with previous work. We find that the self-employment probability is higher for those who are older, more educated, married, and nonveterans. The estimated effect of the number of children and disability status is not easily summarized as they differ more by sample and gender. The estimates are available on request from the authors.

${ }^{27}$ These MA-level controls include the log average income of natives, the native unemployment rate, and the log native population. 
of these controls does not appreciably affect the coefficient estimates on the immigration measures.

We first discuss the results for the self-employment rate, which are reported in specifications 1 and 2. The samples of native men and women used in the first-stage regressions are limited to the working population (ages 16-64). For men, the coefficient estimate on the immigrant share is positive and statistically significant for both the 1980 and 1990 crosssections. Next, we report the estimates for native women. We also find positive and statistically significant coefficient estimates on the immigrant share, although the coefficients are smaller. These results suggest that immigration increases the probability of self-employment among nativeborn male and female workers.

In table 3, we also report estimates for the weighted immigrant share. This measure of immigration addresses the concern that immigrant groups differ in their impact on native self-employment. For example, it is likely that an immigrant from a high self-employment rate group,such as $\mathrm{Cu}$ bans, Koreans, or Russians, has a larger crowding out effect on selfemployed natives than an immigrant from a low self-employment rate group, such as Cambodians, Filipinos, or Mexicans. This observation suggests that we weight the immigrant share in an MA by the propensity of those immigrants to be self-employed. Therefore, we define the weighted immigrant share in MA $m$ as

$$
I_{m}^{W}=\frac{1}{\alpha N_{m}^{T}} \sum_{g=1}^{G} S_{-m g}^{i} N_{m g}^{i},
$$

where $g=1, \ldots, G$ denotes immigrant groups, $\alpha$ is a scaling factor that equates the total number of "weighted" immigrants and the total number of actual immigrants, $S_{-m g}^{i}$ is the self-employment rate (or ratio) for group $g$ using all MAs except MA $m, N_{m g}^{i}$ is the number of immigrants of group $g$ in MA $m$, and $N_{m}^{T}$ is the total population in MA $m \cdot{ }^{28}$ Using the selfemployment rates (or ratios) as weights allows immigrants from highself-employment rate groups to count more than immigrants from low self-employment rate groups. ${ }^{29}$ This reweighting of immigrants does not change our conclusions. For men, the coefficient estimates on the weighted immigrant share are somewhat larger than the coefficient estimates on the immigrant share, and for women the coefficients are only slightly larger. Furthermore, all of the coefficient estimates remain statistically significant.

${ }^{28}$ More details are provided in Fairlie and Meyer (1998).

${ }^{29}$ The weighted immigrant share variables are very similar to the unweighted share variables. The main exception to this pattern is that MAs with many immigrants from Mexico tend to have lower weighted immigrant shares than unweighted immigrant shares, and MAs with many immigrants from Asian countries tend to have higher weighted immigrant shares. 
Specifications 3 and 4 report estimates from the second-stage regressions for the self-employment ratio. The samples used to estimate the first-stage regressions include the entire nonschool, noninstitutionalized population (ages 16-64). The self-employment ratio is a much broader measure of self-employment than the self-employment rate as it also includes individuals who, while primarily self-employed, worked few weeks or few hours per week last year. In addition, the use of this measure does not exclude from the sample someone who may have been displaced from self-employment into unemployment. ${ }^{30}$ For native men and women, the coefficients from using this alternative sample and definition of self-employment are somewhat smaller than those for the self-employment rate. All of the coefficients for the self-employment ratio, however, remain positive and statistically significant. Overall, these results indicate that our estimates of the effects of immigration are not overly sensitive to the chosen measure of self-employment.

The finding of positive and statistically significant coefficient estimates on the immigrant share in the probit regressions is surprising. Thus far, however, we have not determined if these coefficient estimates imply large or small effects of immigration on native self-employment. Recall that our second-stage coefficients are in the same metric as the probit coefficients, making them difficult to interpret. We now convert these coefficients into derivatives.

One useful rescaling of the coefficients is to calculate the implied change in the number of self-employed natives in an MA when one more selfemployed immigrant arrives. This rescaling, referred to below as the scaled derivative, is equal to

$$
\gamma_{I} \varphi(\tilde{w}) N_{L}^{n} \frac{N^{n}}{\left(N^{n}+N^{i}\right)^{2}} \frac{N^{i}}{N_{s}^{i}}
$$

where $\gamma_{I}$ is the coefficient on the immigrant share, $\phi$ is the normal probability density function, $N_{L}^{n}$ is the number of natives in the labor force of the appropriate gender, $N_{S}^{i}$ is the number of self-employed immigrants of either gender, ${ }^{31}$ and $N^{n}$ and $N^{i}$ are the total number of natives and

${ }^{30}$ A simple calculation shows that this second difference is probably of less importance. A self-employed worker displaced into unemployment reduces the numerator of both the self-employment rate and ratio by one and reduces the denominator of the ratio by one but leaves the denominator of the rate unchanged. However, since the denominator is so much larger than the numerator, the resulting difference between the rate and ratio measures will be small.

${ }^{31}$ We use the nonschool, noninstitutionalized population and the broader definition of self-employment for these last two expressions in the case of the selfemployment ratio outcome in order to be compatible with this alternative measure of self-employment. 
immigrants of either gender. ${ }^{32}$ We define $\tilde{w}$ to solve $S^{n}=\Phi(\tilde{w})$, where $S^{n}$ is the native self-employment rate (or ratio) for the relevant gender. Note that $\gamma_{I} \phi(\tilde{w})$ represents the change in the probability of self-employment with respect to a one unit change in the immigrant share (evaluated at the average probability in the sample) and the remainder of (14) represents the needed change in variables to obtain the scaled derivative.

We report estimates of these scaled derivatives in table $3 .^{33}$ The derivative estimates indicate that the coefficients on the immigrant share and weighted immigrant share imply large effects of immigration on native self-employment. The range of derivative estimates implies that an additional self-employed immigrant results in an increase of 0.40 to 1.37 self-employed native men and an increase of 0.18 to 0.23 self-employed native women.

The large, positive, and statistically significant coefficient estimates are unexpected given the hypothesis that immigrants displace self-employed natives. These estimates, however, may be biased due to unobserved MA characteristics that are correlated with native self-employment rates and the immigrant share. In particular, our positive coefficient estimates may be due to an omitted MA fixed effect that both increases the level of native self-employment and is positively correlated with immigration. Examples of omitted MA fixed effects affecting native self-employment include local government business development policies, consumer demand for the goods and services produced by small businesses, and local economic conditions for small businesses. It is not unreasonable that immigrants may be located in the MAs with favorable values of these characteristics for self-employed blacks. At best, the MA-level controls currently included in our second-stage regressions serve as crude proxies for some of these factors.

\section{B. Comparison of 1990 and 1980 Estimates}

We address the issue of a bias in our results from unobservable MA fixed effects by estimating MA-level equations for the change in self-employment between 1980 and 1990, again using a two-stage procedure. We first estimate

\footnotetext{
${ }^{32}$ This formula relies on the implicit assumption that the number of immigrants who are self-employed in an MA is proportional to the number of immigrants in that MA. While crowding out or enclave effects (which work in different directions) would make this assumption not strictly correct, it is unlikely to be far from the truth.

${ }^{33}$ Standard errors for these derivative estimates are not reported, but they are simply equal to the coefficient standard error times the ratio of the derivative estimate to the coefficient estimate.
} 
Table 4

Two-Stage Probit Estimates for Probability of Self-Employment, FirstDifference (1990 - 1980) Second-Stage Regressions

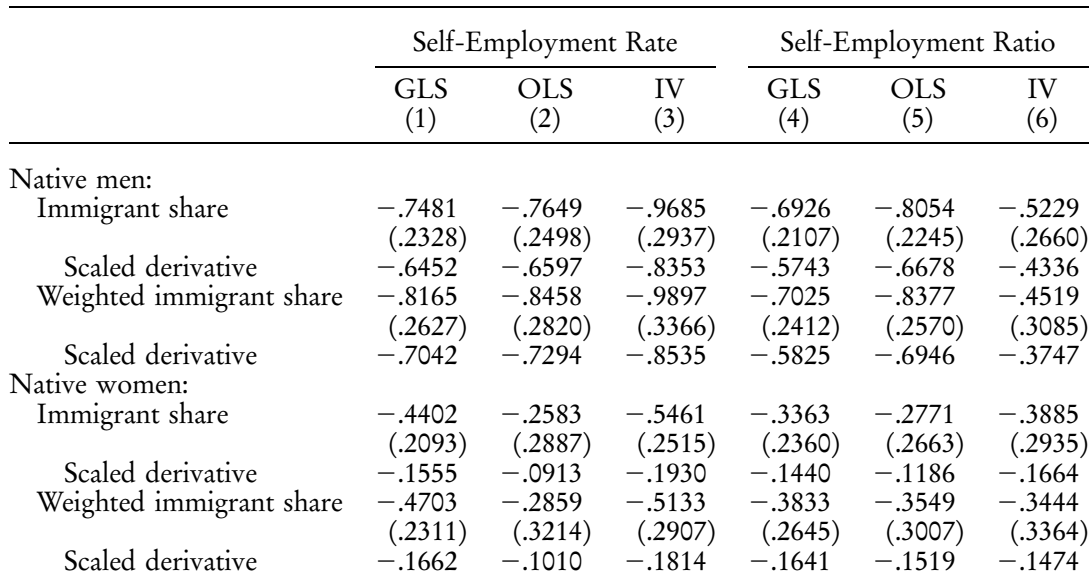

NotE.-Data are from a sample of native-born nonblacks aged 16-64 years living in 132 metropolitan areas. The IV columns use the 1980 immigration variable to instrument for the change between 1980 and 1990. Standard errors are in parentheses. The scaled derivative approximates the change in the number of self-employed natives when the number of self-employed immigrants increases by one. The weighted share weights immigrant groups by their self-employment rate (or ratio). All specifications include 1980 to 1990 changes in log average income of natives, native unemployment rate, and log native population.

a probit equation for the self-employment probability, which uses pooled data from the 1980 and 1990 cross-sections. We rewrite (11) as

$$
\operatorname{Pr}\left(Y_{i m t}=1\right)=\Phi\left(X_{i m t}^{\prime} \beta+\alpha_{m}+\alpha_{m 90}\right),
$$

where $\alpha_{m 90}$ is a fixed effect for MA $m$ in 1990. This equation controls for changes over time as well as differences across individuals in the values of characteristics such as education that are included in $X_{\text {imt }}$. In this equation, $\alpha_{m 90}$ represents the change in the metropolitan area level determinants of self-employment for metropolitan area $m$. The estimates of these firstdifference fixed effects become the dependent variable in the second-stage regression:

$$
\hat{\alpha}_{m 90}=Z_{m 90}^{\prime} \gamma+w_{m}
$$

where $\boldsymbol{Z}_{m 90}^{\prime}$ includes first differences of the immigrant share and other MAlevel characteristics. This equation is a regression of the first difference of the adjusted self-employment tendencies on the first difference of the MAlevel variables. Therefore, these estimates remove any unobserved MA characteristics that affect the self-employment probability and are constant over time.

In table 4, we provide parameter estimates for (16), using our two 
measures of self-employment and three estimation techniques. ${ }^{34}$ These regressions include first differences of all of the MA-level controls that we include in (12) for the 1980 and 1990 MA-level cross-sections. The coefficient estimates on the immigration measures are not overly sensitive to the inclusion of these controls.

We first discuss the results for the GLS regressions, which are reported in specifications 1 and 4 . The dependent variable used in specification 1 is the self-employment rate. For men, the coefficient estimate on the immigrant share is negative and statistically significant. In the second panel, we report the estimates for native women. We also find a negative and statistically significant coefficient estimate on the immigrant share, although the coefficient is smaller. These results suggest that immigration reduces the probability of self-employment among native-born male and female workers.

In table 4, we also report estimates for the weighted immigrant share. This reweighting of immigrants makes little difference in the results. For both men and women, the coefficient estimate on the weighted immigrant share is only slightly larger than the coefficient estimate on the immigrant share. Furthermore, both coefficient estimates remain statistically significant.

Specification 4 reports estimates from the GLS second-stage regressions for the self-employment ratio. For native men, the results from using this alternative sample and definition of self-employment are very similar to those for the self-employment rate. The coefficient estimates for native women are somewhat smaller than those reported in specification 1 and are now statistically insignificant at conventional levels. Overall, these results indicate that our estimates of the effects of immigration are not overly sensitive to the chosen measure of self-employment.

The finding of a negative coefficient on the immigrant share in the probit regressions is consistent with our hypothesis that self-employed immigrants crowd out self-employed natives. Furthermore, the reported derivative estimates indicate that the coefficients on the immigrant share and weighted immigrant share imply large effects of immigration on native self-employment. The derivative estimates imply that an additional selfemployed immigrant results in a decrease of 0.57 to 0.70 self-employed native men and a decrease of 0.14 to 0.17 self-employed native women. Clearly, immigration appears to have a large negative effect on the propensity of natives to choose self-employment.

To check the robustness of these results, we estimate second-stage re-

${ }^{34}$ We estimate the first-stage probit regressions using a choice-based sampling maximum likelihood estimator (CBSMLE). The original sample sizes range from 2.5 to 3.5 million observations. The resulting sample sizes range from 238,847 to 774,074 observations. 
gressions using two additional estimation techniques. In specifications 2 and 5 of table 4 , we report ordinary least squares (OLS) estimates. ${ }^{35}$ The samples and explanatory variables used are the same as those used in specifications 1 and 4. For native men, the OLS coefficient estimates are fairly similar to the GLS estimates in both the self-employment rate and self-employment ratio regressions. In all cases, they remain negative, large, and statistically significant. For native women, the coefficient estimates on the immigration measures are now much smaller in the self-employment rate regressions, but they are similar to the GLS estimates in the self-employment ratio regressions.

Our first-difference estimates eliminate the bias due to MA fixed effects that are correlated with native self-employment and the immigrant share. These estimates, however, do not eliminate potential biases due to MAspecific transitory effects that are correlated with changes in native selfemployment and changes in the immigrant share. In particular, immigrants may choose to live in MAs that are experiencing fast local economic growth. The MAs that are experiencing fast local economic growth are also likely to have increasing levels of native self-employment, thus causing a spurious positive correlation between changes in native self-employment and immigration. ${ }^{36}$ To address this problem, we apply the instrumental variables (IV) approach taken in Altonji and Card (1991). In particular, we use the 1980 value of our immigration measure as an instrument for the change in its value from 1980 to 1990.

We report the IV results in specifications 3 and 6 of table $4 .{ }^{37}$ For native men, the coefficients on the immigrant and weighted immigrant shares become more negative for the self-employment rate. The coefficient estimates, which remain statistically significant, imply that each self-employed immigrant displaces 0.84 to 0.85 self-employed native men. In contrast, the IV estimates for the self-employment ratio are less negative,

${ }^{35}$ A potential problem with the GLS estimates occurs if there is an important omitted variable that is specific to one or a few of the MAs with large regression weights. Because OLS places the same weight on each observation, the effect of such an omitted variable on the coefficient estimates is lessened.

${ }^{36}$ Another potential problem is that the location decisions of immigrants may be directly related to MA levels of native self-employment, implying that the immigrant share is not an exogenous variable in our second-stage regressions. We argue, however, that this is unlikely because self-employment, even for immigrants, represents a relatively small share of the workforce. Further support of this argument is provided by the finding in Bartel (1989) that recent immigrants tend to locate in SMSAs that have large numbers of previous immigrants from the same country and that economic factors have a relatively small effect on location decisions.

${ }^{37}$ The formula for the vector of second-stage coefficient estimates is $\left(\tilde{Z}^{\prime} \Omega^{-1} W\left(W^{\prime} \Omega^{-1} W\right)^{-1} W^{\prime} \Omega^{-1} \tilde{Z}\right)^{-1} \tilde{Z}^{\prime} \Omega^{-1} W\left(W^{\prime} \Omega^{-1} W\right)^{-1} W^{\prime} \Omega^{-1} \hat{\alpha}_{m 90}$, where $\tilde{Z}, \Omega$, and $\hat{\alpha}_{m 90}$ are as defined above and $W$ includes the 1980 immigration measure and first differences of the MA-level controls. 
implying displacement derivatives of 0.37 and 0.43 . For native women, the IV estimates are more negative than the GLS estimates in the selfemployment rate regressions and are similar in the self-employment ratio regressions. Overall, the IV results do not change our conclusions regarding the effect of immigration on native self-employment.

\section{Estimating the Effects of Immigration on Native Self-Employment Earnings}

We now examine the question of whether immigrants depress the earnings of self-employed natives. To answer this question we estimate several regressions in which the dependent variable is the log of self-employment income. ${ }^{38}$ Similar to (15) and (16), we estimate these regressions in two stages. In the first stage, we estimate OLS regressions using our samples of self-employed native men and women. The same independent variables, MA fixed effects, and MA first-difference fixed effects are included as those in (15). The second-stage regression is a regression of the firstdifference fixed effects on first differences (changes from 1980 to 1990) in the MA-level variables. We do not report estimates using the 1980 and 1990 cross-sections. ${ }^{39}$

The results from the second-stage self-employment earnings regressions are reported in table 5. In specifications $1-3$, we report results for the sample of native self-employed workers who meet the hours and weeks worked restrictions of the self-employment rate measure. Specifications 4-6 report results for the less restrictive group of self-employed workers who may work any number of hours and weeks (the self-employment ratio definition). We first discuss the GLS results (specifications 1 and 4).$^{40}$ For both native men and women, the coefficient estimates are positive and statistically significant, implying that immigration increases the earnings of self-employed natives. To determine whether the coefficients imply large or small effects, we calculate scaled derivatives. The scaled derivatives reported in this table represent the change in log earnings (or percentage change in earnings) due to a 0.0364 percentage point change in the immigrant share, which is equal to the change in the immigrant share from 1980 to 1990 for our sample of MAs. Thus, the coefficient estimates imply that an increase in immigration comparable to that experienced in the

\footnotetext{
${ }^{38}$ Self-employment earnings less than 2.718 are set to $e$ before taking logs.

${ }^{39}$ For native men, the coefficients on the immigrant share using the 1980 crosssection are negative and statistically insignificant. The coefficients are positive for the 1990 cross-section, but they are substantially smaller than the first-difference results reported in table 5 . For native women, the coefficients on the immigrant share are positive and statistically significant using the 1980 and 1990 cross-sections, but they are also much smaller than the reported first-difference estimates.

${ }^{40}$ We use the inverse of the variance of the first-difference MA fixed effects as weights in these regressions.
} 
Table 5

Two-Stage Log Self-Employment Earnings Regressions, First-Difference (1990 - 1980) Second-Stage Regressions

\begin{tabular}{|c|c|c|c|c|c|c|}
\hline & \multicolumn{3}{|c|}{$\begin{array}{c}\text { Self-Employment Rate } \\
\text { Definition }\end{array}$} & \multicolumn{3}{|c|}{$\begin{array}{c}\text { Self-Employment Ratio } \\
\text { Definition }\end{array}$} \\
\hline & $\begin{array}{l}\text { GLS } \\
(1)\end{array}$ & $\begin{array}{c}\text { OLS } \\
(2)\end{array}$ & $\begin{array}{l}\text { IV } \\
(3)\end{array}$ & $\begin{array}{c}\text { GLS } \\
(4)\end{array}$ & $\begin{array}{c}\mathrm{OLS} \\
(5)\end{array}$ & $\begin{array}{l}\text { IV } \\
(6)\end{array}$ \\
\hline \multicolumn{7}{|l|}{ Native men: } \\
\hline Immigrant share & $\begin{array}{l}2.4909 \\
(.1494)\end{array}$ & $\begin{array}{l}1.7168 \\
(.3063)\end{array}$ & $\begin{array}{l}3.2020 \\
(.1679)\end{array}$ & $\begin{array}{l}3.0323 \\
(.2138)\end{array}$ & $\begin{array}{l}2.1137 \\
(.4119)\end{array}$ & $\begin{array}{l}3.7693 \\
(.2406)\end{array}$ \\
\hline Scaled derivative & .0907 & .0625 & .1166 & .1104 & .0769 & .1372 \\
\hline Weighted immigrant share & $\begin{array}{l}2.8679 \\
(.1593)\end{array}$ & $\begin{array}{c}2.2222 \\
(.3313)\end{array}$ & $\begin{array}{l}3.7475 \\
(.1874)\end{array}$ & $\begin{array}{c}3.4683 \\
(.2258)\end{array}$ & $\begin{array}{l}2.6765 \\
(.4494)\end{array}$ & $\begin{array}{l}4.3491 \\
(.2661)\end{array}$ \\
\hline \multicolumn{7}{|l|}{ Native women: } \\
\hline Immigrant share & $\begin{array}{l}2.3683 \\
(.3142)\end{array}$ & $\begin{array}{l}1.8005 \\
(.6421)\end{array}$ & $\begin{array}{l}3.0046 \\
(.3514)\end{array}$ & $\begin{array}{l}1.6201 \\
(.4423)\end{array}$ & $\begin{array}{l}1.6314 \\
(.8657)\end{array}$ & $\begin{array}{l}2.3944 \\
(.4957)\end{array}$ \\
\hline Scale & .0862 & .0655 & .1094 & .0590 & .0594 & .0872 \\
\hline Weighted immigrant share & $\begin{array}{l}2.7817 \\
(.3360)\end{array}$ & $\begin{array}{l}2.3173 \\
(.6994)\end{array}$ & $\begin{array}{l}3.6573 \\
(.3929)\end{array}$ & $\begin{array}{l}2.0354 \\
(.4687)\end{array}$ & $\begin{array}{l}1.7434 \\
(.9481)\end{array}$ & $\begin{array}{l}3.2051 \\
(.5504)\end{array}$ \\
\hline Scaled derivative & .1013 & .0844 & .1331 & .0741 & .0635 & .1167 \\
\hline \multicolumn{7}{|c|}{$\begin{array}{l}\text { NoTE.-Data are from a sample of native-born nonblacks aged } 16-64 \text { years living in } 132 \text { metropolitan } \\
\text { areas. The IV columns use the } 1980 \text { immigration variable to instrument for the change between } 1980 \text { and } \\
\text { 1990. Standard errors are in parentheses. The scaled derivative approximates the change in native log self- } \\
\text { employment earnings when the immigrant share increases by the change from } 1980 \text { to } 1990 \text { for our sample } \\
\text { of } 132 \text { MAs ( = .0364). The weighted immigrant share weights immigrant groups by their self-employment } \\
\text { rate (or ratio). All specifications include } 1980 \text { to } 1990 \text { changes in native unemployment rate and log native } \\
\text { population. }\end{array}$} \\
\hline
\end{tabular}

1980s for our sample of 132 MAs increases self-employment earnings by approximately $9 \%-13 \%$ for native men and $6 \%-10 \%$ for native women.

In table 5, we also report estimates from OLS and IV second-stage regressions. The OLS estimates (specifications 2 and 5) are smaller than the GLS estimates, and the IV estimates are larger. ${ }^{41}$ Both estimation strategies, however, provide positive coefficient estimates and do not change our conclusions regarding the effect of immigration on native selfemployment earnings.

${ }^{41}$ An alternative approach to IV that may remove the potential spurious correlation created by immigrants choosing to live in areas that are experiencing fast local economic growth is to use wage/salary workers as a control group. If we assume that immigration has no or only a small effect on natives' wages (as is found in most previous studies), then estimates of the effects of immigration on self-employment earnings relative to wage/salary earnings will provide unbiased estimates of the effects of immigration on native self-employment earnings. To explore this alternative, we estimate two-stage earnings regressions using our samples of all workers. In the second-stage regressions, in which the dependent variable is the first-difference MA fixed effect interacted with a dummy variable for self-employment, we find positive and generally statistically significant coefficients on the immigrant share. In all cases, however, the coefficients are smaller, suggesting that the positive coefficient estimates reported in table 4 may be partly due to a positive correlation between immigration and growth in overall earnings. 
The positive estimates reported in table 5 are puzzling in light of the predictions of the theoretical model. One possible explanation for these results, however, is that self-employed immigrants are primarily displacing natives who own "marginal" businesses. Even if immigration depresses earnings at all points of the earnings distribution, average native selfemployment earnings may increase due to this compositional change. ${ }^{42}$

One method of investigating this hypothesis is to use hours and weeks worked as a proxy for "marginal" businesses and compare the effects of immigration across different groups of self-employed natives based on hours and weeks worked. We first return to the results presented in table 4. If self-employed immigrants primarily displace "marginally" self-employed natives, then we might expect to find larger negative effects on the probability of self-employment when we relax the hours and weeks restrictions. The estimates reported in table 4 run counter to the hypothesis as we generally find less negative coefficient and derivative estimates in the self-employment ratio regressions than in the self-employment rate regressions for both men and women.

Although not reported, we also estimate self-employment probit regressions with samples that include only full-time, full-year workers. ${ }^{43}$ These samples will exclude potentially displaced low-hours self-employed natives who are loosely attached to work. For native men, we find less negative coefficient estimates in some of the specifications, but all of the coefficient estimates remain large and negative. The coefficient estimates are more negative using the full-time, full-year sample for women. ${ }^{44}$

Our comparison of results using various levels of hours and weeks worked restrictions does not provide evidence that immigrants are primarily displacing low-hours (or "marginal") self-employed natives. ${ }^{45}$ This finding, however, does not rule out the possibility that the positive coefficients in the self-employment earnings regressions are due to the displacement of marginal, but high-hours self-employed.

We also estimate a series of employment and earnings equations in

${ }^{42}$ A simple examination of the predicted effects of immigration changes from 1980 to 1990 suggests that the fall in mean earnings is large compared to what one might expect from the exit of marginal businesses.

${ }^{43}$ We define full-time, full-year workers as those who worked at least 40 weeks and usually worked at least 35 hours per week last year.

${ }^{44}$ We also estimate self-employment earnings regressions using the full-time, fullyear sample. We find very similar coefficients on the immigrant and weighted immigrant shares to those reported in table 4 . These results provide further evidence that the positive coefficient estimates on the immigrant share cannot simply be due to the disproportionate displacement of self-employed natives with low hours.

${ }^{45}$ The results for these different groups of workers, however, provide evidence on the robustness of the findings that immigration has a large negative effect on the probability of self-employment among natives and a positive effect on native self-employment earnings. 
which we control for the predicted change in self-employment and selfemployment earnings, using national changes by industry. Based on an MA's industry distribution in 1980, we predicted changes in self-employment rates and earnings using national changes by industry between 1980 and 1990. We then included these predictions in the appropriate regressions. These additional controls tended to slightly decrease the magnitude of the immigration effects, but they had little overall effect on the bottom line provided by the estimates without them.

\section{Explanations for the Effects and Migration Estimates}

The estimates of the effects of immigration on native self-employment in the previous sections suggest some substantial negative effects on natives, although most studies of effects on native wage/salary workers have found little effect. However, these apparently different results are partly due to a different focus and may not be too surprising when other issues are considered.

Most of the immigrant crowding out literature has focused on effects on wages rather than employment. Here we focus first on an employmentbased measure, the self-employment rate or ratio. If the native self-employed disproportionately leave high immigration cities, then we could find that self-employment of natives falls in high immigration cities. A similar hypothesis has been given as an explanation for the small effects of immigration on native wages found in some recent studies (see, e.g., Borjas et al. 1996, 1997). The possibility of migration would seem to be less important a priori for the self-employed since they tend to be less mobile but, if migration changes in response to immigration, there could still be an important effect.

We examine the hypothesis of migration of the self-employed in response to immigration. In particular, we regress the self-employment rate of outmigrants from an MA on the immigrant share from the MA. These results are reported in table 6 . We find some support for the hypothesis of outmigration of native self-employed. In either the 1980 or 1990 cross-section, it appears that out-migrants from high immigration cities are more likely to be self-employed. In both decades, the differential migration of the selfemployed is large and significant. On the other hand, when we examine changes in the self-employment rate among out-migrants, the results are not very supportive of a migration response. The coefficient now is near zero, though it is estimated somewhat imprecisely. Overall, the estimates suggest that selective migration of the self-employed may be a large part of the decline in the self-employment rate in response to immigration.

Furthermore, there are other factors that make displacement of the selfemployed more likely than displacement of wage salary workers. The mobility of capital and traded output tends to diminish the effect on wage/ 
Table 6

Two-Stage Probit Estimates for Probability of Postmigration SelfEmployment, 1980 and 1990, and First-Difference Second-Stage Regressions

\begin{tabular}{|c|c|c|c|}
\hline & & f-Emplc & \\
\hline & $\begin{array}{c}1980 \\
\text { GLS } \\
(1)\end{array}$ & $\begin{array}{c}1990 \\
\text { GLS } \\
(2)\end{array}$ & $\begin{array}{c}\text { First Difference } \\
(1990-1980) \\
\text { GLS } \\
\text { (3) }\end{array}$ \\
\hline Native men immigrant share & $\begin{array}{c}.5487 \\
(.1956)\end{array}$ & $\begin{array}{c}.4439 \\
(.1441)\end{array}$ & $\begin{array}{c}.0595 \\
(.3169)\end{array}$ \\
\hline Native women immigrant share & $\begin{array}{l}.7132 \\
(.2434)\end{array}$ & $\begin{array}{l}.5967 \\
(.1205)\end{array}$ & $\begin{array}{c}-.0981 \\
(.2567)\end{array}$ \\
\hline
\end{tabular}

NoTE.-Data are from a sample of native-born nonblacks aged 16-64 living in 132 metropolitan areas. The sample only includes individuals who moved to a different MA from 1975 to 1980 , or from 1985 to 1990. The female sample only includes 128 MAs. All specifications use GLS and the self-employment rate definition. Standard errors are in parentheses.

salary workers. For example, an influx of low-wage workers in an area may not hurt native low-wage workers if capital floods into the area to support additional businesses and if the product of those businesses can be sold nationally. Both of these additional forces that diminish the observed effect of immigration are likely to be less important for the selfemployed. Mobility of capital probably is not crucial to self-employed given self-finance, or finance through friends and family, rather than through formal financial institutions such as banks. Even if banks are used, they are likely local banks. Since most of the output of the selfemployed is sold locally, there would be less ability to expand markets in response to increased output. In this situation, where each metropolitan area is nearly a closed economy, the effect of immigration may be large.

It is also possible that selective migration of the native self-employed and immigrant concentrations in certain types of business could lead to an increase in measured native self-employment earnings. As mentioned earlier, if immigrants crowd out low-return businesses, it could lead to an increase in measured native returns. For example, ethnic restaurants might crowd out less-expensive native-owned restaurants, but not crowd out more-expensive native-owned restaurants. This would result in a negative effect on the native self-employment rate, but possibly it would have a positive effect on native self-employment earnings.

A final explanation for our results might be that the empirical evidence overstates the effect of immigration for some reason. The most plausible explanation would seem to be that we have omitted variables positively correlated with high immigration that lead to both lower self-employment rates and higher earnings of natives. One possibility is that past immigration and the ethnic makeup of an MA may affect the self-employment rate and be correlated with later immigration. We have explored this issue by examining how a battery of ethnicity/race controls affect the MA 
coefficients in 1980 and 1990 self-employment rate cross-sections. The estimates suggest that these omitted variables are not very important as the MA coefficients change only slightly. Another possibility is that immigrants were directly or indirectly attracted to cities that were more likely to have created extensive minority business development programs in the 1980 s. $^{46}$ These programs were not available to white-owned businesses. Finally, immigrants may have arrived in the cities that had rapidly improving local labor markets, which may have also drawn less-successful self-employed natives into the wage/salary sector. This argument, which is essentially that changes in immigrant shares, even when instrumented with past shares, are not exogenous, is a potential problem with all studies of immigration. Here, as implied by our model, changes in the wage and salary sector will have repercussions for the self-employed as workers choose a sector on the basis of relative returns in the two sectors.

\section{E. Effects of Immigration by Education Level and Additional Estimates}

To further explore the crowding out hypothesis, we estimate the effect of immigration on self-employment probabilities and earnings among natives with different levels of education. We report second-stage GLS results by education level for the self-employment rate in table 7 and for self-employment earnings (using the self-employment rate definition) in table 8 .

The results reported in table 7 provide evidence of strong displacement effects for native men who have the two lowest levels of education (high school dropouts and high school graduates). ${ }^{47}$ The coefficients on the immigrant share are negative and statistically significant. For native men who attended college or who graduated from college, the coefficient on the immigrant share is negative but it is small and statistically insignificant. The results for native women are less clear. The coefficients on the immigrant share are more negative for the two highest education levels, but only the coefficient for those who attended college is significantly different from zero.

The results for self-employment earnings are more similar across ed-

${ }^{46}$ Chay and Fairlie (1998) find some evidence suggesting that the minority business set-aside programs created in many large cities in the 1980 s increased the number of black-owned construction firms.

${ }^{47}$ These two groups of self-employed native men and those who attended but did not graduate from college have large industry concentrations in construction, retail trade, and business and repair services, which represent three of the four largest industry shares for self-employed immigrants. Interestingly, the second largest industry share for self-employed immigrants is professional services, which has the largest share of self-employed native men who are college graduates. 
Table 7

Two-Stage Probit Estimates for Probability of Self-Employment, FirstDifference (1990 - 1980) Second-Stage Regressions by Education Level

\begin{tabular}{|c|c|c|c|c|}
\hline & \multicolumn{4}{|c|}{ Self-Employment Rate } \\
\hline & $\begin{array}{l}\text { High School } \\
\text { Dropout } \\
\text { GLS } \\
(1)\end{array}$ & $\begin{array}{l}\text { High School } \\
\text { Graduate } \\
\text { GLS } \\
(2)\end{array}$ & $\begin{array}{l}\text { Some } \\
\text { College } \\
\text { GLS } \\
(3)\end{array}$ & $\begin{array}{c}\text { College } \\
\text { Graduate } \\
\text { GLS } \\
(4)\end{array}$ \\
\hline \multicolumn{5}{|l|}{ Native men: } \\
\hline Immigrant share & $\begin{array}{r}-1.0777 \\
(.3895)\end{array}$ & $\begin{array}{c}-.6472 \\
(.3065)\end{array}$ & $\begin{array}{c}-.2073 \\
(.2905)\end{array}$ & $\begin{array}{c}-.1244 \\
(.2388)\end{array}$ \\
\hline Scaled derivative & -.1510 & -.1710 & -.0490 & -.0393 \\
\hline Weighted immigrant share & $\begin{array}{r}-1.0804 \\
(.4430)\end{array}$ & $\begin{array}{c}-.6904 \\
(.3456)\end{array}$ & $\begin{array}{c}-.2610 \\
(.3283)\end{array}$ & $\begin{array}{l}-.1595 \\
(.2649)\end{array}$ \\
\hline Scaled derivative & -.1514 & -.1824 & -.0616 & -.0503 \\
\hline \multicolumn{5}{|l|}{ Native women: } \\
\hline Immigrant share & $\begin{array}{r}-.3535 \\
(.4726)\end{array}$ & $\begin{array}{c}-.2973 \\
(.2479)\end{array}$ & $\begin{array}{c}-.5585 \\
(.2162)\end{array}$ & $\begin{array}{l}-.5803 \\
(.4145)\end{array}$ \\
\hline Scaled derivative & -.0163 & -.0396 & -.0638 & -.0578 \\
\hline Weighted immigrant share & $\begin{array}{l}-.3517 \\
(5300)\end{array}$ & $\begin{array}{l}-.2861 \\
(2753)\end{array}$ & $\begin{array}{r}-.6280 \\
(2341)\end{array}$ & $\begin{array}{l}-.6208 \\
(4610)\end{array}$ \\
\hline Scaled derivative & -.0162 & -.0381 & -.0717 & -.0619 \\
\hline
\end{tabular}

Note.-Data are from a sample of native-born nonblacks aged 16-64 years living in 132 metropolitan areas. All specifications use GLS and are for the self-employment rate. Standard errors are in parentheses. The scaled derivative approximates the change in the number of self-employed natives when the number of self-employed immigrants increases by one. The weighted immigrant share weights immigrant groups by their self-employment rate. All specifications include 1980 to 1990 changes in log average income of natives, native unemployment rate, and log native population.

ucation levels. ${ }^{48}$ We find positive and generally statistically significant coefficients on the immigrant share in all of the specifications reported in table 8. These results provide further evidence against the hypothesis that the positive coefficient estimates in the self-employment earnings regressions are due to compositional changes.

\section{Conclusion}

Using 1980 and 1990 Census microdata, we find evidence that immigration has a large negative effect on the probability of self-employment among native nonblacks. Using various estimation techniques and measures of self-employment and immigration, our first-difference estimates indicate that from 0.37 to 0.85 self-employed native men and from 0.09 to 0.19 selfemployed native women are displaced by each self-employed immigrant. These estimates of displacement effects are statistically significant in almost all cases for native men and in some cases for native women.

To be sure, however, our results using the 1980 and 1990 cross-sections do not support this conclusion. In fact, we find positive and statistically significant estimates in these regressions. Furthermore, the first-difference

${ }^{48}$ In table A2 in the appendix, we report earnings for wage/salary workers and the self-employed by education level for our 2 census years. 
Table 8

Two-Stage Log Self-Employment Earnings Regressions, First-Difference (1990 - 1980) Second-Stage Regressions by Education Level

\begin{tabular}{|c|c|c|c|c|}
\hline & \multicolumn{4}{|c|}{ Self-Employment Rate Definition } \\
\hline & $\begin{array}{l}\text { High School } \\
\text { Dropout } \\
\text { GLS } \\
(1)\end{array}$ & $\begin{array}{l}\text { High School } \\
\text { Graduate } \\
\text { GLS } \\
(2)\end{array}$ & $\begin{array}{c}\text { Some } \\
\text { College } \\
\text { GLS } \\
(3)\end{array}$ & $\begin{array}{c}\text { College } \\
\text { Graduate } \\
\text { GLS } \\
(4)\end{array}$ \\
\hline \multicolumn{5}{|l|}{ Native men: } \\
\hline Immigrant share & $\begin{array}{l}2.6426 \\
(.4483)\end{array}$ & $\begin{array}{l}2.9366 \\
(.3034)\end{array}$ & $\begin{array}{l}2.0352 \\
(.3076)\end{array}$ & $\begin{array}{l}2.4884 \\
(.2390)\end{array}$ \\
\hline Scaled derivative & .0962 & .1069 & .0741 & .0906 \\
\hline Weighted immigrant share & $\begin{array}{l}3.2169 \\
(.4782)\end{array}$ & $\begin{array}{l}3.4411 \\
(.3217)\end{array}$ & $\begin{array}{l}2.3359 \\
(.3317)\end{array}$ & $\begin{array}{l}2.7305 \\
(.2539)\end{array}$ \\
\hline Scaled derivative & .1171 & .1253 & .0850 & .0994 \\
\hline \multicolumn{5}{|l|}{ Native women: } \\
\hline Immigrant share & $\begin{array}{l}.8548 \\
(.9245)\end{array}$ & $\begin{array}{l}1.6759 \\
(.5600)\end{array}$ & $\begin{array}{l}2.7280 \\
(.5738)\end{array}$ & $\begin{array}{l}2.2073 \\
(.6641)\end{array}$ \\
\hline Scaled derivative & .0311 & .0610 & .0993 & .0804 \\
\hline Weighted immigrant share & $\begin{array}{c}.9927 \\
(.9985)\end{array}$ & $\begin{array}{l}1.8921 \\
(.5973)\end{array}$ & $\begin{array}{l}3.1935 \\
(.6207)\end{array}$ & $\begin{array}{c}2.5308 \\
(.7044)\end{array}$ \\
\hline Scaled derivative & .0361 & .0689 & .1162 & .0921 \\
\hline
\end{tabular}

NotE.-All specifications use GLS and the self-employment rate definition. Data are from a sample of native-born nonblacks aged 16-64 years living in 132 metropolitan areas. Standard errors are in parentheses. The scaled derivative approximates the change in native log self-employment earnings when the immigrant share increases by the change from 1980 to 1990 for our sample of 132 MAs $(=.0364)$. The weighted immigrant share weights immigrant groups by their self-employment rate. All specifications include 1980 to 1990 changes in native unemployment rate and $\log$ native population.

results also conflict with our general equilibrium model of Section II, which predicted small effects on the native self-employment rate. Although the differences between the empirical findings and theoretical predictions are not fully resolved in this article, we offer some hypotheses about what could lead to the discrepancy. Finally, the first-difference results here differ from those in our previous work, indicating that immigration has no or only a small negative, but statistically insignificant, effect on black selfemployment.

Although we find evidence of substantial crowding out due to immigration, native self-employment was on the rise, in both levels and rates, during the 1980s. From 1980 to 1990 the number of businesses in the United States owned by native-born men and native-born women increased by 720,000 and $1,116,000$, respectively. ${ }^{49}$ Thus, at the national level, self-employed immigrants may have primarily taken away opportunities for natives to start new businesses instead of actually putting many selfemployed natives out of business. This may explain why the potential negative effects of immigration on native self-employment has not been used as a major argument against current U.S. immigration policy.

${ }^{49}$ National self-employment rates increased from $10.4 \%$ to $10.8 \%$ for native men and from $4.0 \%$ to $5.9 \%$ for native women. 
In contrast to our findings for the effects of immigration on the probability of native self-employment, our estimates of the effects of immigration on native self-employment earnings do not have the expected sign. In both native male and female self-employment earnings regressions, we find positive and statistically significant coefficients on the immigrant share, suggesting that immigration increases native self-employment earnings. These surprising results may be due to immigrants primarily displacing marginal or low-income self-employed natives, but our analyses do not provide clear evidence supporting this hypothesis.

\section{Appendix}

Table A1

Industry Distributions for the Self-Employed, 1990

\begin{tabular}{|c|c|c|c|c|}
\hline Industry & $\begin{array}{c}\text { Immigrant } \\
\text { Men } \\
(\%)\end{array}$ & $\begin{array}{l}\text { Native } \\
\text { Men } \\
(\%)\end{array}$ & $\begin{array}{c}\text { Immigrant } \\
\text { Women } \\
(\%)\end{array}$ & $\begin{array}{c}\text { Native } \\
\text { Women } \\
(\%)\end{array}$ \\
\hline Mining & .1 & .3 & .0 & .1 \\
\hline Construction & 15.2 & 20.8 & 1.7 & 3.5 \\
\hline Manufacturing, nondurables & 3.4 & 2.7 & 4.6 & 3.6 \\
\hline Manufacturing, durables & 4.8 & 4.9 & 2.9 & 2.6 \\
\hline Transportation, communica- & & & & \\
\hline tions, and utilities & 6.2 & 4.4 & 2.4 & 2.3 \\
\hline Wholesale trade, durables & 2.2 & 2.9 & 1.3 & 1.4 \\
\hline Wholesale trade, nondurables & 3. & 2. & 2.4 & 1.8 \\
\hline Retail trade & 24.2 & 14.0 & 27.2 & 17.8 \\
\hline $\begin{array}{l}\text { Finance, insurance, and real } \\
\text { estate }\end{array}$ & 5.3 & 8.9 & 6.5 & 9.6 \\
\hline Business and repair services & 9.9 & 11.3 & 11.4 & 12.0 \\
\hline Personal services & 4.8 & 2.8 & 12.4 & 9.7 \\
\hline $\begin{array}{l}\text { Entertainment and recrea- } \\
\text { tional services }\end{array}$ & & & & \\
\hline $\begin{array}{l}\text { tional services } \\
\text { Professional services }\end{array}$ & $\begin{array}{r}1.6 \\
139\end{array}$ & $\begin{array}{r}2.2 \\
18.9\end{array}$ & $\begin{array}{r}1.5 \\
25.3\end{array}$ & $\begin{array}{r}2.4 \\
32.2\end{array}$ \\
\hline $\begin{array}{l}\text { Professional services } \\
\text { Other }\end{array}$ & 4.8 & 3.3 & .6 & 1.1 \\
\hline Sample size & 28,897 & 182,495 & 12,712 & 79,043 \\
\hline
\end{tabular}

NotE.-Data are from a sample of native-born nonblacks aged 16-64 years living in 132 metropolitan areas. Census sample weights are used.

Table A2

Native Self-Employed and Wage/Salary Log Earnings by Education Level

\begin{tabular}{lrrrrr}
\hline & \multicolumn{2}{c}{1980} & & \multicolumn{2}{c}{1990} \\
\cline { 2 - 3 } \cline { 5 - 6 } & Mean & $N$ & & Mean & $N$ \\
\hline Native men: & & & & \\
$\quad$ Self-employed: & 9.84 & 26,341 & & 9.63 & 20,746 \\
$\quad$ High school dropout & 10.05 & 46,004 & & 9.91 & 43,219 \\
$\quad$ High school graduate & 10.10 & 31,477 & & 9.99 & 51,053 \\
$\quad$ Some college & 10.61 & 53,474 & & 10.63 & 67,477 \\
$\quad$ College graduate & 9.78 & 288,638 & & 9.54 & 202,277 \\
Wage/salary: & 10.10 & 514,110 & & 9.96 & 433,646 \\
$\quad$ High school dropout & 10.14 & 286,429 & & 10.05 & 457,246 \\
$\quad$ High school graduate & 10.51 & 324,118 & & 10.56 & 414,137 \\
$\quad$ Some college & & & &
\end{tabular}


Table A2 (Continued)

\begin{tabular}{|c|c|c|c|c|}
\hline & \multicolumn{2}{|c|}{1980} & \multicolumn{2}{|c|}{1990} \\
\hline & $\overline{\text { Mean }}$ & $N$ & $\overline{\text { Mean }}$ & $N$ \\
\hline \multicolumn{5}{|l|}{ Native women: } \\
\hline High school dropout & 8.86 & 5,864 & 8.75 & 7,109 \\
\hline High school graduate & 8.92 & 16,173 & 8.94 & 21,980 \\
\hline Some college & 9.04 & 9,490 & 9.11 & 26,725 \\
\hline College graduate & 9.14 & 8,896 & 9.57 & 23,229 \\
\hline \multicolumn{5}{|l|}{ Wage/salary: } \\
\hline High school dropout & 9.08 & 172,990 & 9.02 & 133,652 \\
\hline High school graduate & 9.43 & 476,809 & 9.45 & 401,495 \\
\hline Some college & 9.49 & 228,257 & 9.57 & 437,070 \\
\hline College graduate & 9.84 & 188,231 & 10.03 & 316,539 \\
\hline
\end{tabular}

\section{References}

Altonji, Joseph G., and Card, David. "The Effects of Immigration on the Labor Market Outcomes of Less-Skilled Natives.” In Immigration, Trade, and the Labor Market, edited by John M. Abowd and Richard B. Freeman, pp. 201-34. Chicago: University of Chicago Press, 1991.

Amemiya, Takeshi. Advanced Econometrics. Cambridge, MA: Harvard University Press, 1985.

Bartel, Ann P. "Where Do the New U.S. Immigrants Live?" Journal of Labor Economics 7, no. 4 (October 1989): 371-91.

Benus, Jacob M.; Wood, Michelle L.; Napierala, Christopher J.; and Johnson, Terry R. "Massachusetts UI Self-Employment Demonstration." In Self-Employment Programs for Unemployed Workers. Unemployment Insurance Occasional Paper no. 92-2. Washington, DC: U.S. Department of Labor, Employment, and Training Administration, Unemployment Insurance Service, 1992.

Blanchflower, David G., and Oswald, Andrew J. "What Makes an Entrepreneur?" Journal of Labor Economics 16, no. 1 (January 1998): 26-60.

Borjas, George. "The Self-Employment Experience of Immigrants.” Journal of Human Resources 21 (Fall 1986): 487-506.

-. "Self-Selection and the Earnings of Immigrants." American Economic Review 77, no. 4 (September 1987): 531-53.

. "The Economics of Immigration." Journal of Economic Literature 32, no. 4 (December 1994): 1667-717.

Borjas, George J.; Freeman, Richard B.; and Katz, Lawrence F. "Searching for the Effect of Immigration on the Labor Market." American Economic Review: Papers and Proceedings 86 (May 1996): 246-51.

- "How Much Do Immigration and Trade Affect Labor Market Outcomes?" Brookings Papers on Economic Activity, no. 1 (1997): 1-90.

Borjas, George, and Sueyoshi, Glen. "A Two-Stage Estimator for Probit Models with Structural Group Effects.” Journal of Econometrics 64 (September/October 1994): 165-82. 
Bound, John, and Holzer, Harry J. "Demand Shifts, Population Adjustments, and Labor Market Outcomes during the 1980s." Working Paper no. 5685. Cambridge, MA: National Bureau of Economic Research, 1996.

Brown, Charles; Hamilton, James; and Medoff, James. Employers Large and Small. Cambridge, MA: Harvard University Press, 1990.

Chay, Kenneth Y., and Fairlie, Robert W. "Minority Business Set-Asides and Black Self-Employment.” Working paper. Santa Cruz: University of California, Santa Cruz, Department of Economics, 1998.

Devine, Theresa J. "Changes in Wage-and-Salary Returns to Skill and the Recent Rise in Female Self-Employment." American Economic Review 84, no. 2 (May 1994): 108-13.

Fairlie, Robert W. "Earnings Growth among Less-Educated Business Owners." Industrial Relations, forthcoming.

Fairlie, Robert W., and Meyer, Bruce D. "Ethnic and Racial Self-Employment Differences and Possible Explanations." Journal of Human Resources 31( Fall 1996): 757-93.

. "Does Immigration Hurt African-American Self-Employment?" In Help or Hindrance? The Economic Implications of Immigration for African Americans, edited by Daniel S. Hamermesh and Frank D. Bean, pp. 185-221. New York: Russell Sage Foundation, 1998.

Friedberg, Rachel M., and Hunt, Jennifer. "The Impact of Immigrants on Host Country Wages, Employment, and Growth." Journal of Economic Perspectives 9, no. 2 (Spring 1995): 23-44.

Glazer, Nathan, and Moynihan, Daniel P. Beyond the Melting Pot: The Negroes, Puerto Ricans, Jews, Italians, and Irish of New York City. 2d ed. Cambridge, MA: MIT Press, 1970.

Guy, Cynthia; Doolittle, Fred; and Fink, Barbara. Self-Employment for Welfare Recipients: Implementation of the SEID Program. New York: Manpower Demonstration Research Corporation, 1991.

Holtz-Eakin, Douglas; Joulfaian, David; and Rosen, Harvey. "Entrepreneurial Decisions and Liquidity Constraints." Rand Journal of Economics 23, no. 2 (1994): 334-47.

Immigration and Naturalization Service. 1995 Statistical Yearbook of the Immigration and Naturalization Service. Washington, DC: U.S. Government Printing Office, 1997.

Jaeger, David A. "Regional and Local Area Impacts of Immigration on Natives' Wages.” Working paper. Washington, DC: U.S. Department of Labor, Bureau of Labor Statistics, 1996.

Kinzer, Robert H., and Sagarin, Edward. The Negro in American Business. New York: Greenberg, 1950.

Light, Ivan. Ethnic Enterprise in America. Berkeley: University of California Press, 1972.

Light, Ivan, and Rosenstein, Carolyn. Race, Ethnicity, and Entrepreneurship in Urban America. New York: De Gruyter, 1995.

Light, Ivan, and Sanchez, Angel A. "Immigrant Entrepreneurs in 272 SMSAs." Sociological Perspectives 30, no. 4 (1987): 373-99.

Loeb, Susanna; Turner, Sarah; and Jaeger, David. "Coding Geographic 
Areas across Census Years: Creating Consistent Definitions of Metropolitan Areas." Unpublished manuscript. Ann Arbor: University of Michigan, Department of Economics, 1996.

Min, Pyong Gap. Caught in the Middle: Korean Merchants in America's Multiethnic Cities. Berkeley: University of California Press, 1996.

Raheim, Salome. "Problems and Prospects of Self-Employment as an Economic Independence Option for Welfare Recipients." Social Work 42, no. 1 (1997): 44-53.

U.S. Bureau of the Census. Census of Population and Housing, 1990: Public Use Microdata Sample U.S. Technical Documentation. Washington, DC: U.S. Government Printing Office, 1993.

- 1992 Economic Census: Characteristics of Business Owners. Washington, DC: U.S. Government Printing Office, 1996.

U.S. Department of Labor. Self-Employment Programs for Unemployed Workers. Unemployment Insurance Occasional Paper no. 92-2. Washington, DC: U.S. Government Printing Office, 1992.

U.S. Small Business Administration. Women in Business. Washington, DC: Office of Advocacy, 1998.

Yoon, In-Jin. "Immigrant Entrepreneurship: Korean Business in Chicago." Working paper. Chicago: University of Chicago, Graduate School of Business, 1991.

. On My Own: Korean Businesses and Race Relations in America. Chicago: University of Chicago Press, 1997.

Yuengert, Andrew M. "Testing Hypotheses of Immigrant Self-Employment." Journal of Human Resources 30, no. 1 (Winter 1995): 194-204. 